\title{
PENERAPAN MODEL POE2WE DALAM UPAYA MENGURANGI TERJADINYA MISKONSEPSI PADA POKOK BAHASAN HUKUM ARCHIMEDES
}

\author{
Resty Ilema ${ }^{1}$ Nana $^{2}$ \\ Program Studi Pendidikan Fisika \\ Fakultas Keguruan Dan Ilmu Pendidikan Universitas Siliwangi \\ Tasikmalaya 46115, Jawa Barat, Indonesia \\ Email : restyilema9c26@gmail.com
}

\begin{abstract}
Abstrak
Kesalahan konsep dalam bidang IPA terutama fisika terjadi di banyak tempat mulai dari tingkat pendidikan dasar sampai pendidikan tinggi. Maka, penelitian ini bertujuan untuk : (1) mereduksi miskonsepsi siswa pada pokok bahasan hukum Archimedes (2) menggunakan model pembelajaran POE2WE untuk mengurangi miskonsepsi siswa dalam pokok bahasan hukum Archimedes. Sejalan dengan tujuan tersebut, maka penelitian ini menggunakan metode studi pustaka. Pembelajaran dengan model POE2WE merupakan salah satu model pembelajaran yang dapat membantu siswa dalam membangun pengetahuannya sendiri. Dan dengan menggunakan model ini diharapkan dapat memberikan upaya dalam mengurangi terjadinya miskonsepsi pada siswa dalam setiap pembelajaran yang dijalani. Dalam pembahasan kali ini yaitu dalam pokok bahasan hukum Archimedes akan melihat bagaimana siswa memahami konsep hukum Archimedes dengan sintaks POE2WE yang dilakukan dalam pembelajaran.
\end{abstract}

Kata Kunci : Miskonsepsi, Model POE2WE, Hukum Archimedes

\begin{abstract}
Misconceptions in the field of science especially physics occur in many places ranging from primary education to tertiary education. Thus, this study aims to: (1) reduce student misconceptions on the subject of Archimedes law (2) use the POE2WE learning model to reduce student misconceptions on the subject of Archimedes law. In line with these objectives, this study uses literature study methods. Learning with the POE2WE model is one of the learning models that can help students build their own knowledge. And using this model is expected to provide efforts to reduce the occurrence of misconceptions in students in each learning undertaken. In the discussion this time namely in the subject of Archimedes law will see how students understand the concept of Archimedes's law with the syntax of POE2WE which is done in learning.
\end{abstract}

Keywords: Misconception, POE2WE Model, Archimedes Law 


\section{PENDAHULUAN}

Menurut Pebriyanti (2015), Mata pelajaran fisika pada jenjang SMA memiliki beberapa tujuan, diantaranya adalah agar siswa memiliki kemampuan : mengembangkan kemampuan bernalar dalam berpikir analisis induktif dan deduktif dengan menggunakan konsep dan prinsip fisika untuk menjelaskan berbagai peristiwa alam dan penyelesaian masalah baik secara kualitatif maupun kuantitatif (2) menguasai konsep dan prinsip fisika serta mempunyai keterampilan mengembangkan pengetahuan, dan sikap percaya diri sebagai bekal untuk melanjutkan pendidikan pada jenjang yang lebih tinggi serta mengembangkan ilmu pengetahuan dan teknologi

Menurut Nana (2018), Seorang guru harus melihat siswa bukan seperti lembaran kosong atau tabula rasa, mereka sudah membawa pengetahuan awal, pengetahuan yang mereka punyai adalah dasar untuk membangun pengetahuan selanjutnya. Dengan pengalaman dan pengetahuan yang telah dimiliki siswa, akan terbentuk suatu intuisi dan teori siswa yang belum tentu intuisi dan teori tersebut benar. Intuisi ini membentuk suatu prakonsep yang sederhana sampai yang komplek, cukup logis, konsisten serta sulit untuk di reduksi. Pembentukan prakonsep ini merupakan kerangka alternatif hasil pengalaman yang dibangun oleh siswa.

melalui asimilasi dan akomodasi, dengan demikian siswa yang memasuki kelas sudah penuh dengan prakonsep atau praanggapan mengenai yang akan diajarkan. Guru tidak menyadarai dan memperhitungkan prakonsepsi tersebut dan siswa sendiri tidak menyadarinya.
Penguasaan konsep adalah kemampuan yang memungkinkan seseorang dapat berbuat sesuatu. Hal ini dapat diartikan bahwa tanpa menguasai konsep tertentu, orang tidak dapat berbuat banyak dan mungkin kelangsungan hidupnya akan terganggu. (Gagne, Brings dan Wagner dalam Ibrahim, 2012) (dalam witanecahya dan Jatmiko, 2014). Fisika merupakan salah satu mata pelajaran yang terdiri atas berbagai konsep yang sangat dekat dengan kehidupan sehari-hari. Siswa tidak memasuki pembelajaran Fisika di kelas dengan kepala kosong yang dapat diisi dengan pengetahuan fisika. Tetapi sebaliknya, kepala siswa sudah penuh dengan pengalaman dan pengetahuan yang berhubungan dengan Fisika. Semua siswa sudah berpengalaman dengan gerak, gaya, benda jatuh bebas, listrik, energi, dan banyak peristiwa Fisika lainnya (Berg, 1991).

Mengingat siswa sendiri yang mengkontruksikan pengetahuannya, maka tidak mustahil dapat terjadi kesalahan dalam mengkonstruksi. Kadang-kadang konsep awal yang telah dibangun siswa tidak sesuai dengan konsep ilmiah yang sudah disepakati oleh para ahli. Keadaan demikian disebut dengan miskonsepsi. Menurut Sutrisno, Kresnadi, dan Kartono (2007: 3-6) (dalam Fadriani, 2013) salah satu penyebab miskonsepsi adalah kemampuan berpikir siswa. Dalam proses pembelajaran sering kali siswa mengalami kesulitan dalam memahami konsep fisika khususnya pada hukum Archimedes. Kesulitan belajar ini dapat disebabkan karena guru jarang sekali mengaitkan konsep fisika dengan contoh sederhana dalam kehidupan sehari-hari yang 
dapat siswa amati. Hal ini akan mempengaruhi hasil belajar siswa. Oleh karena itu, perlu dicari cara untuk mengatasi miskonsepsi siswa pada hukum Archimedes. Menurut Nana (2018), Model pembelajaran Prediction, Observation, Eksplanation, Elaboration, Write, dan Evaluation (POE2WE) dikembangkan dari model pembelajaran POEW dan model pembelajaran Fisika dengan Pendekatan Konstruktivisme. Model POE2WE merupakan model pembelajaran yang dikembangkan untuk mengetahui pemahaman siswa mengenai suatu konsep dengan pendekatan kontruktivistik.

Maka penelitian ini bertujuan untuk memberikan upaya dalam mereduksi miskonsepsi siswa dalam pembelajaran fisika khususnya pada pokok pembahasan Hukum Archimedes dengan bantuan model pembelajaran POE2WE yang menggunakan pendekatan Konstruktivisme.

\section{METODE PENELITIAN}

Penelitian ini menggunakan metode studi pustaka, dengan mengkaji beberapa teori dasar yang relevan dengan topik yang akan dibahas, menggali teori-teori yang relevan dengan pembahasan untuk menemukan konsep-konsep yang sesuai dengan pokok masalah yang dibahas tentang penggunaan model POE2WE. Dan juga untuk menemukan suatu masalah untuk diteliti, dalam arti bukti-bukti atau pernyataan bahwa masalah yang akan diteliti belum terjawab atau belum terpecahkan secara memuaskan atau belum pernah diteliti orang mengenai tujuan, data dan metode, analisa dan hasil untuk waktu dan tempat yang sama. Dalam membahas suatu topik dengan menggunakan studi pustaka berupa jurnal, buku ataupun artikel untuk menguji kebenaran topik yang diteliti.

\section{HASIL PENELITIAN DAN PEMBAHASAN}

Salah satu miskonsepsi dalam mata pelajaran fisika pada hukum archimedes menurut Utami (2013)(dalam Dewi dkk.,2016) antara lain 1) Semakin besar massa jenis suatu zat cair, maka benda yang dicelupkan pada zat cair tersebut akan semakin berat 2) siswa menganggap sebuah benda yang berat pasti akan tenggelam. 3) Siswa menganggap tenggelamnya suatu benda dikarenakan berat benda, dan 4) siswa menganggap massa benda menentukan peristiwa terapung, melayang, dan tenggelam. Dalam pembelajaran dibutuhkan klarifikasi konsep yang sudah dibangun siswa, sehingga konsep yang telah dibangun siswa menjadi lebih benar tentunya.

Menurut Nana (2018), Model POE2WE merupakan model pembelajaran yang dikembangkan untuk mengetahui pemahaman siswa mengenai suatu konsep dengan pendekatan konstruktivistik. Model ini membangaun pengetahuan dengan urutan proses terlebih dahulu meramalkan atau memprediksi solusi dari permasalahan, melakukan eksperimen untuk membuktikan prediksi, kemudian menjelaskan hasil eksperimen yang diperoleh secara lisan maupun tertulis, membuat contoh penerapan dalam kehidupan sehari-hari, menuliskan hasil diskusi dan membuat evaluasi tentang pemahaman siswa baik secara lisan maupun tertulis.

Penggabungan tahapan-tahapan pembelajaran model POEW dan model 
pembelajaran Fisika dengan Pendekatan Konstruktivistik maka dapat di susun langkahlangkah pembelajaran model POE2WE secara terinci sebagai berikut:

a) Prediction

Tahap prediction yaitu siswa membuat prediksi atau dugaan awal terhadap suatu permasalahan. Permasalahan yang ditemukan berasala dari pertanyaan dan gambar tentang gerak lurus oleh guru yang ada di LKS/buku siswa sebelum siswa membuat prediksi. Pembuatan prediksi jawaban tahap Prediction pada model POEW identik dengan fase Engagenent pada pendekatan konstruktivistik. Guru mengajukan pertanyaan yang dapat mendorong siswa untuk dapat membuat prediksi atau jawaban sementara dari suatu permasalahan.

b) Observation

Tahap Observation yaitu untuk membuktikan prediksi yang telah di buat oleh siswa. Siswa diajak melakukan eksperimen berkaitan dengan masalah atau persoalan yang di temukan. Selanjutnya siswa mengamati apa yang terjadi, kemudian siswa menguji kebenaran dari dugaan sementara yang telah dibuat. Tahap Observation pada model POEW identik dengan fase Exploration pada pendekatan konstruktivistik.

c) Explanation

Tahap Explanation atau menjelaskan yaitu siswa memberikan penjelasan terhadap hasil eksperimen yang telah dilakukan. Penjelasan dari siswa dilakukan melalui diskusi dengan anggota kelompok kemudian tiap kelompokn mempresentasikan hasil diskusinya di depan kelas. Jika prediksi yang di buat siswa ternyata terjadi di dalam eksperimen, maka guru membimbing siswa merangkum dan memberi penjelasan untuk menguatkan hasil eksperimen yang dilakukan. Namun jika prediksi siswa tidak terjadi dalam eksperimen, maka guru membantu siswa mencari penjelasan mengapa prediksi atau dugaannya tidak benar. Tahap explanation identik dengan fase explanation pada pendekatan konstuktivistik.

d) Elaboration

Tahap elaboration yaitu siswa membuat contoh atau menerapkan konsep dalam kehidupan sehari-hari. Tahap elaboration di ambil dari pendekatan konstruktivistik. Tahap ini guru medorong siswa untuk menerapkan konsep baru dalam situasi baru sehingga siswa lebih memahami konsep yang di ajarkan guru. Tahap ini pengembangan dari pendekatan konstruktivistik.

e) Write

Tahap write atau menulis yaitu melakukan komunikasi secara tertulis,merefleksikan pengetahuan dan gagasan yang dimiliki siswa. Menurut Masingilia dan Wisniowska (1996) dalam Ansari (2012) menulis dapat membantu siswa untuk mengekspresikan pengetahuan dan gagasan mereka. Siswa menuliskan hasil diskusi dan menjawab pertanyaan yang ada pada LKS. Selain itu pada tahap write ini, siswa membuat kesimpulan dan laporan dari hasil eksperimen. Tahap ini merupakan pengembangan dari model TTW. 
f) Evaluation

Tahap Evaluationyaitu evaluasi terhadap pengetahuan, keterampilan dan perubahan proses berfikir siswa. Pada tahap ini siswa di evaluasi tentang materi gerak lurus berupa lisan maupun tulisan.Tahap ini merupakan pengembangan dari pendekatan konstruktivistik.

Penerapan dalam mengupayakan miskonsepsi siswa pada pembelajaran fisika khususnya dalam pokok bahasan Hukum Archimedes dapat dilakukan dengan sintaks POE2WE yaitu Prediction, Observation, Eksplanation, Elaboration, Write, dan Evaluation. Dari ke enam sintaks tersebut memiliki kegiatannya masing - masing. Dapat kegiatannya disisipkan dengan kegiatan siswa berdasarkan pendekatan konstruktivisme yaitu pada sintaks prediction. Dan dalam mengupayakan proses tidak terjadinya atau mereduksi miskonsepsi siswa, maka kita dapat menggunakannya dalam sintaks Observation dan Eksplanation.

Berikut ini adalah penerapan upaya mengurangi dan mereduksi miskonsepsi siswa dalam pembelajaran fisika yaitu pada pokok bahasan Penerapan Hukum Archimedes pada proses tenggelam, terapung, dan Melayang dengan menggunakan sintaks Model POE2WE :

\section{a) Prediction}

Langkah awal adalah melakukan prediksi oleh siswa. Mula-mula guru memberikan suatu permasalahan terkait proses Tenggelam, terapung dan melayang hal ini di kaitkan dengan masalah yang ada di kehidupan guna memudahkan siswa dalam membuat suatu prediksi. Biasanya pada sintaks inilah siswa membuat prediksi sesuai dengan apa yang dia pernah lakukan atau apa yang pernah ia lihat sesuai dengan masalah tersebut. Ini adalah pendekatan kontruktivisme pada siswa untuk meningkatkan proses berpikir kritis pada siswa.

b) Observation

Langkah berikutnya adalah melakukan suatu pengamatan atau observasi terkait masalah yang telah disampaikan oleh guru. Pada saat inilah guru memulai proses pendekatan untuk mereduksi miskonsepsi pada siswa yaitu dengan melakukan suatu percobaan kecil dengan alat peraga atau media lainnya yang dapat membantu siswa untuk menganalisis proses tersebut. Pada sintaks ini harus dilakukan oleh siswa dan di awasi guru agar siswa dapat berpikir kreatif dan berkolaborasi dengan baik kepada teman temannya.

c) Eksplanation

Setelah melakukan percobaan, siswa akan berpikir lebih terbuka terkait masalah tersebut kemudian beberapa hal atau fakta yang diberikan guru dan percobaan sebelum akan meyakinkan siswa pada konsep hukum Archimedes yang sesungguhnya sehingga siswa akan terus berpikir apakah konsep yang dia pahami benar atau salah. Dan pada sintaks ini, guru berperan aktif untuk mereduksi pemahaman dan memberikan penjelasan yang sejelas-jelasnya guna untuk menghindari siswa untuk berpikir tidak sesuai dengan konsep yang ada. Guru menjawab semua masalah yang 
telah disampaikan dengan di hubungkan oleh percobaan yang dilakukan.

d) Elaboration

Pada tahap ini, guru memberikan penjelasan mengenai apa saja yang berkaitan dengan konsep hukum Archimedes pada proses tenggelam, terapung dan melayang dikehidupan sehari-hari. Lalu guru menjelaskan apa saja manfaat yang dapat kita ambil dan kita rasakan dari konsep tersebut .

e) Write

Pada tahap ini siswa diminta menulis semua pemahaman yang telah ia dapatkan dari tahap Prediction sampai Elaboration. Guna untuk melihat apakah masih terdapat siswa yang miskonsepsi dari konsep Archimedes.

f) Evaluation

Tahap terakhir dari sintaks POE2WE yaitu melakukan evaluasi . evaluasi disini adalah memberikan siswa beberapa pertanyaan atau masalah terkait hukum Archimedes. Hal ini pun dapat dijadikan dalam upaya mereduksi atau mengurangi miskonsepsi siswa dari konsep Hukum Archimedes

Dari data diatas dapat kita lihat sintaks dalam pembelajaran menggunakan model POE2WE dapat dijadikan upaya untuk mengurangi miskonsepsi siswa pada pembelajaran fisika. Mengapa demikian, karena dari sintaks prediction hingga Evaluation terdapat kegiatan siswa dan guru dalam memahami setiap konsep fisika yang ada dan sintaks tersebut memberikan kemudahan pada guru untuk mengetahui apakah siswa mengalami miskonsepsi atau tidak karena dengan berulang ulang guru dapat menguji pemahaman konsep pada siswa.

\section{KESIMPULAN}

Berdasarkan hasil dan pembahasan diatas dapat disimpulkan bahwa penerapan Model POE2WE dapat memberikan upaya dalam mengurangi miskonsepsi pada siswa terkait pokok bahasan Hukum Archimedes pada proses Tenggelam, terapung dan melayang. Sehingga dengan adanya indentifikasi miskonsepsi siswa pada pembelajaran fisika melalui sintaks POE2WE, maka guru dapat mengetahui cara mengatasi miskonsepsi tersebut.

\section{UCAPAN TERIMA KASIH}

Penulis mengucapkan terima kasih kepada Dr.Nana, M.Pd selaku dosen Jurusan Pendidikan Fisika Universitas Siliwangi yang telah membimbing dalam pembuatan jurnal ini.

\section{DAFTAR PUSTAKA}

Dewi,N.A.,Kusairi,S.,Yuliati,L.(2016).Misk onsepsi Siswa SMA pada Materi Hukum Archimedes.Prosiding Seminar Nasional Tahun 2016.[online].Tersedia:http://lib.um.ac .id/index.php/2017/09/05/miskonsepsi -siswa-sma-pada-materi-hukumarchimedes/ [14 Februari 2020].

Fadriani,Edy,Erwina.(2013).Remediasi Miskonsepsi Hukum Archimedes Dengan Model Two Stay Two Stray Berbantuan Lembar Kerja Berstruktur.Jurnal Pendidikan dan pembelajaran

Khatulistiwa.[online].Tersedia:http://j 
urnal.untan.ac.id/index.php/jpdpb/artic le/view/3559/3567 [14 Februari 2020]

Nana, (2018). Implementasi Model POE2WE dengan Pendekatan Saintifik dalam Pembelajaran Gerak Lurus di SMA.Seminar Nasional Pendidikan Sains.[online].Tersedia:https://www.ju rnal.fkip.uns.ac.id/index.php/snps/artic le/view/12477 [14 Februari 2020].

Nana, (2018). Penggunaan Pendekatan Konflik Kognitif untuk Remediasi Miskonsepsi Pembelajaran Suhu dan Kalor.[online].Tersedia:https://www.ju rnal.fkip.uns.ac.id/index.php/snps/artic le/view/12476 [14 Februari 2020].

Pebriyanti,D.,Sahidu,H.,Sutrio.(2015).Efekti fitas Model Pembelajaran Perubahan Konseptual Untuk Mengatasi Miskonsepsi Fisika Pada Siswa Kelas $\mathrm{X}$ SMAN 1 Praya Barat Tahun Pelajaran 2012/2013.Jurnal Pendidikan Fisika Dan Teknologi. Volume 1, Nomor 1.

Witanecahya,S.Z.,Jatmiko,B.(2014).Penerap an Model Pembelajaran Inkuiri Terbimbing (Guided Inquiry) untuk Mengurangi Miskonsepsi Siswa Kelas X SMAN 2 Ponorogo pada Pokok bahasan Perpindahan Panas.Jurnal Inovasi Pendidikan Fisika, Volume 03.Nomor 03. 